Article

\title{
The Potential Benefits and Limitations of Corn Cob and Sewage Sludge Biochars in an Infertile Oxisol
}

\author{
Jonathan L. Deenik ${ }^{1, *}$ and Michael J. Cooney ${ }^{2}$ \\ 1 Department of Tropical Plant and Soil Sciences, University of Hawaii, Honolulu, HI 96822, USA \\ 2 Hawaii Natural Energy Institute, University of Hawaii, Honolulu, HI 96822, USA; mcooney@hawaii.edu \\ * Correspondence: jdeenik@hawaii.edu; Tel.: +1-808-956-6906; Fax: +1-808-956-3894
}

Academic Editor: Zhiyong Jason Ren

Received: 4 December 2015; Accepted: 26 January 2016; Published: 29 January 2016

\begin{abstract}
The thermal conversion of sewage sludge to biochar offers a promising alternative use for a hazardous waste material with potential benefits to agricultural productivity and soil quality. Three short-term greenhouse experiments were conducted to evaluate the effect of corn cob (CC) and sewage sludge (SS) biochars, with their anaerobically treated counterparts, on soil properties and plant growth in an infertile Oxisol. The anaerobically treated SS biochar showed the greatest concentration of bioavailable essential nutrients, but treatment only resulted in increased yields for the SS biochar in the first crop in the absence of added fertilizer. Both CC and SS biochars in combination with fertilizer doubled plant growth compared to the control in the first crop cycle, produced no significant effect in the second cycle, and more than tripled plant growth for the SS biochars in the third cycle. High ash content with high nutrient contributions (especially P) and a persistent liming effect explain the benefits of the SS biochars to plant growth. The SS biochar showed promise in mitigating the negative effects of soil Mn toxicity. Sewage sludge biochars reduced $\mathrm{Cd}$ bioavailability and had no significant effect on the bioavailability of other potentially toxic metals compared to the control.
\end{abstract}

Keywords: biochar; sewage sludge; soil fertility; ash content; liming effect; plant growth

\section{Introduction}

Managing sewage sludge is one of the most challenging and urgent problems facing an increasingly urban global population [1]. A growing urban global population has resulted in alarming increases in sludge production; China, for example, produced approximately $5 \mathrm{M} \mathrm{T}$ of dewatered sludge in 2009 up from 3.5 M T in 1998 [2] whereas recent estimates show that the European Union produces more than $10 \mathrm{M} \mathrm{T}$ annually [3], and in the United States according to the latest available data annual sludge production is approximately 6.5 MT [4]. Traditional methods of disposal (land application, incineration, and landfilling) pose significant threats to environmental quality and human health [1]. In island environments where land is limited, sludge disposal is of particular concern. In Hawaii, for instance, rapid population growth and urbanization on the island of Oahu and limited landfill capacity has forced the consideration of alternatives to sludge disposal in landfills [5].

Thermal conversion of waste biomass to biochar offers a range of proposed benefits to agriculture and society as a whole [6-9]. Of particular interest, is the opportunity to convert hazardous materials such as sewage sludge into biochar, which when added to soils has the potential to improve soil quality and crop performance [10-12]. Sewage sludge derived biochars are typically high in mineral ash content, which could serve as a source of soluble essential plant nutrients and contribute liming potential in acidic soils [13]. While there is an interest in the use of sewage sludge biochars to increase soil productivity and an increasing number of studies characterizing the properties of sewage sludge 
derived biochars [14-18], there are limited studies showing benefits of sewage sludge biochar to plant growth [19-22]. There is a large and growing body of literature indicating that biochar applications to soil increase crop productivity and improve soil fertility and quality [23]. From an agronomic perspective, some of the benefits of biochar to soils include increased soil porosity and water holding capacity, increased aeration, increased aggregate stability, reductions in bulk density and tensile strength [24], augmented nutrient retention through enhanced cation exchange capacity [25], direct contribution of essential plant nutrients [26,27], a liming effect mitigating of nutrient deficiencies and elemental toxicities in acid soils [13,28], enhancement of plant-microbe symbioses [29], and more recently observations indicating possible stimulatory effects on plant phytohormones [30]. Along with the apparent benefits, there are reported negative effects from the application of some biochars to soil $[7,23]$; specifically, reduced soil $\mathrm{N}$ resulting in stunted plant growth $[28,31]$ potential phytoxic effects from biochar derived polycyclic aromatic hyrocarbons (PAHs) [32,33], and some evidence for increased bioavailability of As [34].

Biochar's absorbant properties lend its use as an effective material in remediating contaminated soils [35-37], reducing bioavailability of heavy metals [21,38] in soils and water [39,40], and as a substrate supporting enhanced microbial colonization in anaerobic digestion systems [41]. In addition to its ability to promote microbe colonization and increase the efficiency of anaerobic digestion systems, biochar has the capacity to adsorb essential plant nutrients such as inorganic $\mathrm{N}$ and $\mathrm{P}[42,43]$ during the digestion process imparting a potential fertilizer value to the biochar. Two recent studies suggest that biochar surfaces sorbed a high amount of inorganic $\mathrm{P}$ under controlled conditions, and that the $\mathrm{P}$ was bioavailable when the biochar was added to soil stimulating plant growth $[44,45]$.

Given the critical need to find alternative strategies for improving waste water management and sewage sludge disposal, the overall goal of this study was to evaluate the use of sewage sludge biochar to improve crop growth in an infertile soil. Specific objectives were (1) to compare the effect of a high ash sewage sludge biochar with a lower ash corn cob biochar on corn growth; and (2) to evaluate whether using both biochars in an anaerobic digestion system improved their fertilizer value when applied to soil. We hypothesized that the high ash sewage sludge biochar would increase crop growth more than the corn cob biochar, and that both anaerobically treated biochars would be enriched in $\mathrm{N}$ and $\mathrm{P}$ and increase crop growth above their untreated counterparts.

\section{Materials and Methods}

\subsection{Biochars}

Corn cob feedstock was obtained from waste piles at the Pioneer Seed Company facility located in Central Oahu in 2011. Sewage sludge was obtained from the Hawaii Kai wastewater treatment plant, Honolulu County, in 2011 (a secondary treatment facility). Both feedstocks were carbonized utilizing the Flash Carbonization process where the de-watered feedstocks were placed in a pressurized canister (1.14 MPa) and carbonized with maximum temperature reaching $600{ }^{\circ} \mathrm{C}$ for $20 \mathrm{~min}$ [46]. Following carbonization of each feedstock, the biochars were homogenized, and separated into two batches. One batch of each biochar was sent for use as a biofilm support material in a high rate anaerobic digestion apparatus used to remediate wastewater separated from grease trap waste [41]. The remaining batches were stored at room temperature in ziplock bags. Following their use in the anaerobic digestion experiments, the CC and SS biochars were removed from the digestors and air-dried in the laboratory. The treated and untreated biochars were crushed to pass a $2 \mathrm{~mm}$ sieve, and a subsample of each collected for analysis.

The uncarbonized feedstock and the treated and untreated biochars were sent to Hazen Laboratories (Hazen Research, Inc., Golden, CO, USA) where they were analyzed for proximate and ultimate analysis, main ash elements according to ASTM D2795 and ASTM D3682, respectively, and heavy metals according to Environmental Protection Agency EPA series 7000 methods. Total C (TC) and total $\mathrm{N}$ (TN) content of the biochars were determined by dry combustion on a LECO CN-2000 (St. Joseph, MI, USA). Biochar pH was measured in 1:1 slurry of biochar to deionized water. 
Extractable base cations $\left(\mathrm{Ca}^{2+}, \mathrm{K}^{+}, \mathrm{Mg}^{2+}, \mathrm{Na}^{+}\right)$and cation exchange capacity [47] were measured in a $1 \mathrm{M}$ ammonium acetate solution buffered at $\mathrm{pH} 7, \mathrm{P}$ was analyzed colorimetrically by the Murphy and Riley method in a $0.5 \mathrm{M} \mathrm{NaHCO}_{3}$ extract (Olsens) [48], and exchangeable $\mathrm{NH}_{4}{ }^{+}$and $\mathrm{NO}_{3}{ }^{-}{ }^{-} \mathrm{N}$ in a $2 \mathrm{M}$ $\mathrm{KCl}$ extract. Cations were measured by inductive coupled plasma mass spectrometry on a Thermo Jarrell Ash Atom Scan 16 instrument (Franklin, MA, USA), and $\mathrm{NH}_{4}{ }^{+}$and $\mathrm{NO}_{3}-\mathrm{N}$ were determined by the salicylate-hypochlorite method [49] and $\mathrm{NO}_{3}{ }^{-}$by cadmium reduction [50], respectively, using an EasyChem discrete analyzer (Oak Brook, IL, UAS).

\subsection{Greenhouse Experiments}

A series of greenhouse biossays were installed to investigate the effect of biochar applications on soil properties and corn growth in an infertile Oxisol (Wahiawa series, very fine, kaolinitic, isohyperthermic, Rhodic Haplustox). The soil is a silty clay with $\mathrm{pH}$ of 6.15 , total organic carbon (TOC) and TN of 12.6 and $1.50 \mathrm{~g} \cdot \mathrm{kg}^{-1}$, respectively, and extractable $\mathrm{P}, \mathrm{K}, \mathrm{Ca}, \mathrm{Mg}$ and $\mathrm{Na}$ of 8.31, 427, 686, 219 , and $54.6 \mathrm{mg} \cdot \mathrm{kg}^{-1}$, respectively. Treatments consisted of four biochars, untreated corncob (CC UT) and sewage sludge (SS UT) and their treated counterparts (CC T and SS T) applied to the soil at a $2.5 \%(\mathrm{w} / \mathrm{w})$ loading rate each with and without a complete fertilizer application. There were two control treatments-the unamended soil and the soil with the complete fertilizer. All treatments were replicated four times.

The experiments were conducted in sequence between August 2011 and March 2012 beginning with the sewage sludge biochars. Biochar treatments were mixed thoroughly with $2.1 \mathrm{~kg}$ of oven dry equivalent soil and the soil mixtures were packed into plastic pots (diam. $=0.16 \mathrm{~m}$, vol. $=3016 \mathrm{~cm}^{3}$ ) to achieve a bulk density of approximately $1.1 \mathrm{Mg} \cdot \mathrm{m}^{-3}$, brought to $50 \%$ moisture content $(\mathrm{w} / \mathrm{w})$, which is equivalent to approximately $-33 \mathrm{kPa}$ [51], and allowed to stabilize in the greenhouse for two weeks replenishing water twice weekly. Eight seeds of maize (Zea mays, L cv. Super Sweet \#9) were planted and thinned to 2 plants per pot ten days after planting. A complete fertilizer containing $100 \mathrm{mg} \mathrm{N}$ and $\mathrm{K}$ per kg soil as $\mathrm{NH}_{4} \mathrm{NO}_{3}$ and $\mathrm{KCl}, 100 \mathrm{mg} \mathrm{P}$ as $\mathrm{Ca}\left(\mathrm{H}_{2} \mathrm{PO}_{4}\right)_{2}$ (this high rate was required to account for the high $\mathrm{P}$ fixation capacity of the Wahiawa soil); magnesium at $100 \mathrm{mg} \cdot \mathrm{kg}^{-1}$ as $\mathrm{MgCl}_{2} \cdot 6 \mathrm{H}_{2} \mathrm{O}$; and zinc $(\mathrm{Zn})$ at $10 \mathrm{mg} \cdot \mathrm{kg}^{-1}$ as $\mathrm{ZnSO}_{4} \cdot 7 \mathrm{H}_{2} \mathrm{O}$ was applied in solution at planting. Two weeks after planting, an additional $50 \mathrm{mg} \mathrm{N}$ and $\mathrm{K}$ per $\mathrm{kg}$ soil were applied in solution. Soil water was maintained at $50 \%(\mathrm{w} / \mathrm{w})$ and was corrected every $2-3$ days by weighing the pots and adding water to return pots to original water content (during watering events careful attention was taken to minimize water loss due to leaching). The above ground biomass was harvested after five weeks, dried at $70{ }^{\circ} \mathrm{C}$ for $72 \mathrm{~h}$, and weighed for dry biomass. Roots were separated from the soil by hand, washed carefully, dried, and weighed. Soils were mixed thoroughly, a $100 \mathrm{~g}$ sub-sample removed for analysis, stored at $4{ }^{\circ} \mathrm{C}$ prior to laboratory analyses, and the remaining soil returned to their respective pots for follow-up experiments. The same procedure was employed for the 2 nd and 3 rd crops, except that fertilizer applications included $\mathrm{N}, \mathrm{K}$ and $\mathrm{Zn}$ at the rates mentioned above, but $\mathrm{P}$ and $\mathrm{Mg}$ applications were reduced to $40 \mathrm{mg} \cdot \mathrm{kg}^{-1}$.

\subsection{Soil and Plant Analyses}

At the end of each corn growth cycle, dried above ground biomass was ground in a Wiley mill,

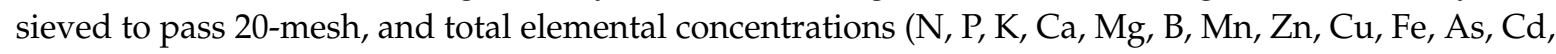
$\mathrm{Co}, \mathrm{Cr}, \mathrm{Ni}, \mathrm{Pb}$, and $\mathrm{Se})$ were determined on a 0.50-g dried tissue samples digested in $\mathrm{HNO}_{3} / \mathrm{H}_{2} \mathrm{O}_{2}(1 / 1$ $\mathrm{v} / \mathrm{v}$ ) [52]. Soil pH, TOC, TN, P and extractable base cations were analyzed according to the procedures outlined for biochar analysis. The soils from the third crop cycle were extracted for $\mathrm{Mn}$ in a saturated paste and analyzed by ICP [53]. Due to the lack of sufficient soil samples, replicates 1 and 2, and 3 and 4 were pooled, homogenized, and analyzed separately for a total of 6 samples.

\subsection{Statistical Analyses}

Statistical analysis was performed separately on each crop cycle for the two biochars because the experiments were not run concurrently. Treatment effects on plant growth and soil properties were 
analyzed by one-way ANOVA using PROC ANOVA in SAS 9.2 (SAS Institute, Inc., Middleton, MA, USA, 2002). Where data did not mean the assumption of equal variances, ANOVA was performed on transformed data, but reported in their untransformed format. In case of significant effects, multiple mean comparisons were done using Tukey's Studentized post-hoc procedures at $\mathrm{P}<0.05$.

\section{Results}

\subsection{Biochars}

As expected, the CC and SS biochars showed contrasting chemical properties and variable response to carbonization (Table 1). The CC biochar was C-rich, but low in N, S and ash constituents compared with the sludge biochar. Low O:C and $\mathrm{H}: \mathrm{C}$ ratios and low $\mathrm{VM}$ content in both of the untreated biochars indicate a high level of thermal alteration and aromaticity. Especially noteworthy were the very high ash and $\mathrm{N}$ contents in the SS biochar. The main ash components of the two biochars were considerably different and responded differently to carbonization. The CC biochar showed depletions in $\mathrm{SiO}_{2}$ and $\mathrm{CaO}$ and enrichments in $\mathrm{MgO}, \mathrm{Na}_{2} \mathrm{O}, \mathrm{K}_{2} \mathrm{O}$, and $\mathrm{P}_{2} \mathrm{O}_{5}$ compared to the feedstock whereas carbonization had minimal effects on ash constituents in the SS material. Thermal treatment tended to concentrate heavy metals in both biochars with increases more substantial for the sewage sludge materials.

Table 1. Ultimate, proximate, ash components and heavy metal analyses for untreated (UT) and treated $(\mathrm{T})^{\dagger}$ corn cob (CC) and Hawaii Kai sewage sludge (SS) biochars and feedstocks.

\begin{tabular}{|c|c|c|c|c|c|c|c|c|c|c|}
\hline \multirow[t]{2}{*}{ Biochar } & \multicolumn{5}{|c|}{ Ultimate Analysis } & \multicolumn{5}{|c|}{ Proximate Analysis } \\
\hline & $\mathrm{C}$ & $\mathrm{H}$ & $\mathrm{O}$ & $\mathrm{N}$ & $\mathrm{S}$ & $\mathrm{FC}^{\mathrm{a}}$ & $\mathrm{VM}^{\mathrm{b}}$ & ash & & \\
\hline \multicolumn{11}{|c|}{$\%$} \\
\hline $\mathrm{CC}^{\mathrm{c}}$ & 48.7 & 5.75 & 42.2 & 0.51 & 0.06 & NA & NA & 2.83 & & \\
\hline CC UT & 84.9 & 2.42 & 2.66 & 0.89 & 0.13 & 80.3 & 8.26 & 11.4 & & \\
\hline $\mathrm{CC} \mathrm{T}$ & 84.3 & 2.80 & 4.47 & 0.91 & 0.16 & 84.8 & 9.64 & 5.61 & & \\
\hline $\mathrm{SS}^{\mathrm{c}}$ & 37.7 & 5.22 & 14.6 & 7.05 & 3.58 & NA & NA & 31.9 & & \\
\hline SS UT & 30.2 & 1.29 & $<0.01$ & 3.13 & 3.81 & 25.8 & 8.64 & 65.5 & & \\
\hline SS T & 30.5 & 0.54 & $<0.01$ & 2.62 & 4.26 & 25.2 & 4.29 & 70.5 & & \\
\hline \multicolumn{11}{|c|}{ Main Ash Components } \\
\hline & $\mathrm{SiO}_{2}$ & $\mathrm{Al}_{2} \mathrm{O}_{3}$ & $\mathrm{Fe}_{2} \mathrm{O}_{3}$ & $\mathrm{TiO}_{2}$ & $\mathrm{CaO}$ & $\mathrm{MgO}$ & $\mathrm{Na}_{2} \mathrm{O}$ & $\mathrm{K}_{2} \mathrm{O}$ & $\mathrm{P}_{2} \mathrm{O}_{5}$ & $\mathrm{SO}_{3}$ \\
\hline & \multicolumn{10}{|c|}{$\%$} \\
\hline $\mathrm{CC}^{\mathrm{c}}$ & 52.1 & 1.52 & 1.30 & 0.13 & 2.46 & 1.90 & 0.36 & 21.00 & 8.56 & 2.54 \\
\hline CC UT & 22.2 & 1.57 & 5.41 & 0.25 & 1.79 & 2.64 & 7.19 & 36.9 & 10.1 & 2.84 \\
\hline $\mathrm{CC} \mathrm{T}$ & 20.1 & 1.45 & 4.54 & 0.24 & 1.62 & 3.31 & 11.0 & 23.6 & 12.7 & 4.03 \\
\hline $\mathrm{SS}^{\mathrm{c}}$ & 13.4 & 4.79 & 23.3 & 1.17 & 9.11 & 3.69 & 8.44 & 2.36 & 21.3 & 12.5 \\
\hline SS UT & 14.4 & 5.68 & 21.2 & 1.39 & 9.13 & 3.99 & 8.61 & 2.13 & 20.9 & 11.9 \\
\hline \multirow[t]{3}{*}{ SS T } & 14.5 & 5.79 & 22.5 & 1.46 & 9.41 & 4.29 & 5.42 & 1.91 & 22.4 & 10.6 \\
\hline & \multicolumn{10}{|c|}{ Heavy Metals } \\
\hline & As & $\mathrm{Cd}$ & $\mathrm{Cr}$ & $\mathrm{Cu}$ & $\mathrm{Hg}$ & Mo & $\mathrm{Ni}$ & $\mathrm{Pb}$ & Se & $\mathrm{Zn}$ \\
\hline & \multicolumn{10}{|c|}{$\mathrm{mg} \cdot \mathrm{kg}^{-1}$} \\
\hline $\mathrm{CC}^{\mathrm{c}}$ & 0.18 & 0.1 & 9.56 & 4.27 & $<0.01$ & 2.8 & 1 & 1.5 & $<0.05$ & 35.1 \\
\hline CC UT & 0.56 & 0.5 & 24.7 & 24 & 0.59 & 16.4 & 14 & 2.1 & 0.89 & 164 \\
\hline $\mathrm{SS}^{\mathrm{c}}$ & 4.66 & 3.2 & 65 & 346 & 0.28 & 9 & 27 & 14 & 8.58 & 1030 \\
\hline SS UT & 16.7 & 6.0 & 170 & 712 & 0.11 & 13 & 71 & 60 & 14.0 & 2360 \\
\hline SS T & 18.2 & 7.0 & 182 & 766 & $<0.01$ & 24 & 74 & 81 & 14.9 & 3190 \\
\hline USEPA $^{d}$ & 75 & 85 & NR & 4300 & 57 & 75 & 420 & 840 & 100 & 7500 \\
\hline Hawaii ${ }^{e}$ & 20 & 15 & 200 & 1500 & 10 & 15 & 100 & 300 & 25 & 2000 \\
\hline
\end{tabular}

${ }^{\mathrm{a}}$ fixed carbon; ${ }^{\mathrm{b}}$ volatile matter; ${ }^{\mathrm{c}}$ raw material, ${ }^{\mathrm{d}}$ ceiling concentrations US EPA [54], ${ }^{\mathrm{e}}$ ceiling concentrations for State of Hawaii [55]; ${ }^{\dagger}$ insufficient sample for analysis. 
The biochar materials showed inconsistent response to anaerobic treatment. Ash content was reduced 2-fold in the treated CC biochar, but showed an increase for the treated SS biochar. For N and S, the CC biochar showed only small changes while treatment reduced $\mathrm{N}$ and increased $\mathrm{S}$ concentrations. Treatment effects were more consistent with regards to the ash constituents where treatment increased $\mathrm{MgO}, \mathrm{Na}_{2} \mathrm{O}$, and $\mathrm{P}_{2} \mathrm{O}_{5}$, but reduced $\mathrm{K}_{2} \mathrm{O}$ compared with the untreated biochars. The pronounced loss of $\mathrm{K}_{2} \mathrm{O}$ in the treated $\mathrm{CC}$ biochar was the most noteworthy effect of treatment on the ash constituents. For the SS biochars, treatment, generally, showed an increase in all metals except $\mathrm{Hg}$.

The biochars showed large differences in $\mathrm{pH}$ and the readily soluble fraction of macronutrients and $\mathrm{Na}$ (Table 2). The CC biochars were alkaline whereas the SS biochars were slightly acidic. The untreated SS biochar showed higher concentrations of soluble $\mathrm{NH}_{4}{ }^{+}-\mathrm{N}, \mathrm{P}, \mathrm{Ca}$ and $\mathrm{Na}$, but lower $\mathrm{K}$ and $\mathrm{Mg}$ compared to the $\mathrm{CC}$ biochar. For both treated biochars, treatment increased $\mathrm{P}, \mathrm{Ca}$ and $\mathrm{Mg}$ with the increases more pronounced in the SS biochar. There was a consistent loss of $\mathrm{K}$ in both treated biochars compared to their untreated counterparts, but for $\mathrm{NH}_{4}{ }^{+}-\mathrm{N}$ and $\mathrm{Na}$ treatment had opposite effects on the two biochars; for the $\mathrm{CC}$ biochar treatment increased both $\mathrm{NH}_{4}{ }^{+}-\mathrm{N}$ and $\mathrm{Na}$ while treatment showed considerable reductions in the concentrations of these two elements in the SS biochar.

Table 2. Biochar $\mathrm{pH}, \mathrm{CEC}$, and concentrations of extractable nutrients. Values represent the mean of three replicates, values in parentheses are one standard deviation.

\begin{tabular}{cccccccccc}
\hline Sample & $\mathbf{p H}$ & $\mathbf{C E C}$ & $\mathbf{N H}_{\mathbf{4}}{ }^{+}-\mathbf{N}$ & $\mathbf{N O}_{3}{ }^{-}-\mathbf{N}$ & $\mathbf{P}$ & $\mathbf{K}^{+}$ & $\mathbf{C a}^{++}$ & $\mathbf{M g}^{++}$ & $\mathbf{N a}^{+}$ \\
\hline \multicolumn{7}{c}{$\mathrm{cmol}_{\mathrm{c}} \cdot \mathrm{kg}^{-1}$} \\
\hline CC UT & $9.20(0.03)$ & $11.3(1.27)$ & $10.6(0.8)$ & $1.04(1.41)$ & $129(18.5)$ & $16,371(1286)$ & $136(12.2)$ & $432(39.2)$ & $535(95.6)$ \\
CC T & $9.45(0.24)$ & $\mathrm{NA}^{\mathrm{a}}$ & $24.7(12.8)$ & $0.03(0.06)$ & $175(35.8)$ & $10,547(5025)$ & $140(12.9)$ & $471(38.4)$ & $4416(3457)$ \\
SS UT & $6.81(0.06)$ & $15.5(0.10)$ & $216(34.3)$ & $\mathrm{ND}^{\mathrm{b}}$ & $372(90.2)$ & $1200(274)$ & $1240(242)$ & $190(27.0)$ & $11,077(2985)$ \\
SS T & $6.86(0.02)$ & $\mathrm{NA}$ & $33.3(5.6)$ & $\mathrm{ND}$ & $1285(19.6)$ & $1015(163)$ & $1683(313)$ & $255(55.1)$ & $4205(647)$ \\
\hline
\end{tabular}

${ }^{\mathrm{a}}$ Not measured; ${ }^{\mathrm{b}}$ below the detection limit.

\subsection{Plant Growth}

In the absence of fertilizers, both the untreated and treated CC biochars had no effect on corn growth across all three growing cycles (Figure 1a-c). On the other hand, the untreated SS biochar (without fertilizer) more than tripled corn biomass compared to the unfertilized soil and was on par with the fertilized control in the first crop cycle (Figure 1d), but the positive effect did not persist through the $2^{\text {nd }}$ and $3^{\text {rd }}$ crop cycles (Figure 1e,f). The combination of biochar and fertilizer produced significant benefits to corn growth compared with the fertilizer alone treatments in the 1st and 3rd crop cycles. In the first crop, fertilizer+biochar combinations for both biochar types doubled corn growth (Figure 1a,d) and more than tripled growth in the 3rd crop for the SS biochars (Figure 1f). 

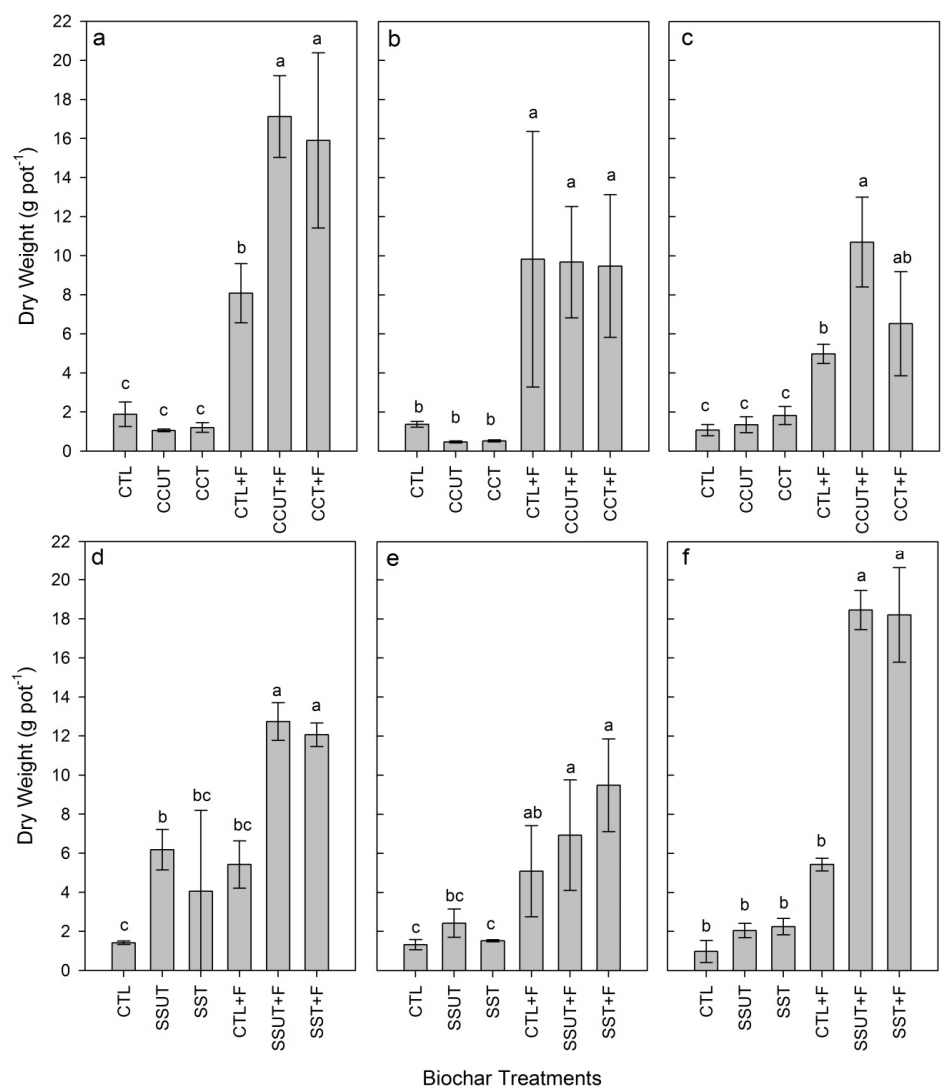

Figure 1. Corn cob biochar effects on corn above-ground dry matter production in crop cycle 1 (a); 2 (b); and 3 (c). Sewage sludge biochar effects on corn above-ground dry matter production in crop cycle 1 (d); 2 (e); and 3 (f).

\subsection{Soil Properties}

Biochar amendment had immediate and mostly beneficial effects on soil properties, but there were some important differences due to both biochar type and anaerobic treatment. Treating the two biochars increased their liming potential compared with their untreated counterpart raising $\mathrm{pH}$ by one unit to 7.00 for the treated CC biochar, but the improvement was smaller for the treated SS biochar (Table 3). Both CC biochars more than doubled soil C content with no treatment effect while the treated SS biochar was more effective at raising soil $\mathrm{C}$. The larger increase in soil $\mathrm{C}$ from $\mathrm{CC}$ biochar amendment is a reflection of the high fixed $\mathrm{C}$ content of the CC biochar. Contrary to expectations, despite a much lower total $\mathrm{N}$ content, the CC biochars increased soil $\mathrm{N}$ content two-fold, but the high N SS biochars had no effect on soil N compared with the unamended soil. Both treated biochars significantly increased soil $\mathrm{P}$ and $\mathrm{Mg}$ above their untreated counterparts and the control soil. Both treated and untreated biochars increased soil $\mathrm{Ca}$ above the control, but showed no differences due to treatment. On the other hand, both biochars significantly increased soil $\mathrm{K}$, but the untreated biochars showed the greatest effect.

There were noteworthy differences in how biochar type and treatment affected soil properties over the three crop cycles in relation to fertilization. In the absence of a fertilizer treatment, soil $\mathrm{pH}$ showed some increases in the control soil, an increase with the untreated CC biochar, and no change with the treated biochar. For the SS biochars there was a consistent drop in $\mathrm{pH}$ with the treated biochar, but only an initial drop with the untreated biochar from the first to second crops followed by no change. In the fertilized treatments, however, $\mathrm{pH}$ dropped consistently with each subsequent crop cycle and the decreases were more pronounced in the unamended soil where the $\mathrm{pH}$ dropped by more than one unit in the CC experiments and by approximately one unit in the SS experiments. Although the SS biochars were generally less effective in raising soil $\mathrm{pH}$ in comparison to the $\mathrm{CC}$ biochars, they 
appeared more effective at buffering the soil against the acidifying effects of the fertilizer. Soil $\mathrm{pH}$ decreases from the pre-plant to third harvest were $0.99,0.28$, and 0.51 for the control, untreated and treated SS biochars, respectively. For the CC experiments where $\mathrm{pH}$ decreases from fertilizer were more severe (1.62 units in the control soils), the untreated biochar reduced $\mathrm{pH}$ decline to 0.89 units, but its treated counterpart by 1.8 units.

Table 3. Biochar effects on selected soil chemical properties over three corn cropping cycles. Values are the means of four replicates where same letter within the same biochar type and cropping cycle denotes no significant difference $(\mathrm{P}<0.05)$.

\begin{tabular}{|c|c|c|c|c|c|c|c|}
\hline Treatment & $\mathrm{pH}$ & TC & TN & $\mathbf{P}$ & $\mathbf{K}$ & $\mathrm{Ca}$ & Mg \\
\hline & & \multicolumn{2}{|c|}{$\mathrm{g} \cdot \mathrm{kg}^{-1}$} & \multicolumn{4}{|c|}{$\mathrm{mg} \cdot \mathrm{kg}^{-1}$} \\
\hline \multicolumn{8}{|c|}{ Corn Cob Biochar } \\
\hline \multicolumn{8}{|c|}{ Crop Cycle 1} \\
\hline Control & $6.16^{b}$ & $12.6^{b}$ & $1.5^{\mathrm{b}}$ & $8.31^{b}$ & $427^{c}$ & $686^{b}$ & $219^{c}$ \\
\hline Untreated & $6.31^{\mathrm{b}}$ & $26.11^{a}$ & $3.0^{\mathrm{a}}$ & $10.7^{b}$ & $1083^{a}$ & $768^{a}$ & $258^{b}$ \\
\hline Treated & $7.00^{\mathrm{a}}$ & $27.2^{\mathrm{a}}$ & $3.2^{\mathrm{a}}$ & $16.8^{\mathrm{a}}$ & $849^{b}$ & $812^{a}$ & $296^{a}$ \\
\hline \multicolumn{8}{|c|}{ Crop Cycle 2} \\
\hline Control & $6.33^{b}$ & NA & NA & $6.50^{c}$ & $377^{d}$ & $714^{b}$ & $248^{a}$ \\
\hline Control + F & $5.56^{\mathrm{d}}$ & NA & NA & $10.5^{b c}$ & $316^{d}$ & $709^{b}$ & $242^{a}$ \\
\hline Untreated & $6.67^{\mathrm{a}}$ & NA & NA & $10.2^{b c}$ & $926^{a}$ & $904^{\mathrm{a}}$ & $245^{a}$ \\
\hline Untreated + F & $6.00^{\mathrm{c}}$ & NA & NA & $14.8^{\mathrm{ab}}$ & $704^{b}$ & $660^{\mathrm{b}}$ & $236^{a}$ \\
\hline Treated & $6.99^{a}$ & NA & NA & $10.0^{b c}$ & $665^{b}$ & $902^{a}$ & $243^{a}$ \\
\hline Treated + F & $6.27^{b c}$ & NA & NA & $21.6^{\mathrm{a}}$ & $551^{\mathrm{c}}$ & $694^{b}$ & $247^{a}$ \\
\hline \multicolumn{8}{|c|}{ Crop Cycle 3} \\
\hline Control & $6.53^{b}$ & $11.7^{\mathrm{c}}$ & $1.3^{\mathrm{b}}$ & $7.54^{\mathrm{d}}$ & $154^{\mathrm{d}}$ & $754^{\mathrm{ab}}$ & $207^{a b}$ \\
\hline Control + F & $4.58^{\mathrm{d}}$ & $14.2^{\mathrm{C}}$ & $1.6^{\mathrm{b}}$ & $14.8^{b c}$ & $222^{d}$ & $650^{a b}$ & $181^{a b}$ \\
\hline Untreated & $6.73^{b}$ & $30.7^{\mathrm{a}}$ & $3.3^{\mathrm{a}}$ & $7.76^{\mathrm{d}}$ & $917^{\mathrm{a}}$ & $830^{\mathrm{a}}$ & $243^{a b}$ \\
\hline Untreated + F & $5.44^{\mathrm{c}}$ & $26.5^{\mathrm{b}}$ & $3.0^{\mathrm{a}}$ & $16.9^{\mathrm{ab}}$ & $393^{c}$ & $531^{b}$ & $150^{b}$ \\
\hline Treated & $7.08^{a}$ & $29.6^{a b}$ & $3.4^{\mathrm{a}}$ & $12.2^{c}$ & $608^{b}$ & $872^{a}$ & $247^{\mathrm{a}}$ \\
\hline Treated + F & $5.17^{\mathrm{c}}$ & $28.8^{a b}$ & $3.3^{\mathrm{a}}$ & $19.6^{\mathrm{a}}$ & $347^{c}$ & $544^{\mathrm{b}}$ & $162^{a b}$ \\
\hline \multicolumn{8}{|c|}{ Sewage Sludge Biochar } \\
\hline \multicolumn{8}{|c|}{ Crop Cycle 1} \\
\hline Control & $6.23^{b}$ & $10.5^{\mathrm{c}}$ & $2.1^{\mathrm{a}}$ & $13.8^{b}$ & $285^{c}$ & $957^{b}$ & $251^{\mathrm{c}}$ \\
\hline Untreated & $6.07^{c}$ & $15.7^{b}$ & $1.8^{\mathrm{a}}$ & $24.1^{b}$ & $434^{\mathrm{a}}$ & $1137^{\mathrm{a}}$ & $363^{b}$ \\
\hline Treated & $6.59^{\mathrm{a}}$ & $17.8^{\mathrm{a}}$ & $2.1^{\mathrm{a}}$ & $31.9^{\mathrm{a}}$ & $375^{b}$ & $1092^{\mathrm{a}}$ & $385^{\mathrm{a}}$ \\
\hline \multicolumn{8}{|c|}{ Crop Cycle 2} \\
\hline Control & $6.40^{\mathrm{a}}$ & NA & NA & $8.88^{c}$ & $184^{\mathrm{a}}$ & $835^{d}$ & $227^{b}$ \\
\hline Control + F & $5.43^{\mathrm{c}}$ & NA & NA & $8.28^{\mathrm{c}}$ & $199^{a}$ & $900 b^{c}$ & $239^{b}$ \\
\hline Untreated & $5.82^{b}$ & NA & NA & $30.0^{\mathrm{a}}$ & $211^{\mathrm{a}}$ & $945^{b}$ & $351^{a}$ \\
\hline Untreated + F & $5.73^{b}$ & NA & NA & $22.5^{b}$ & $211^{a}$ & $1055^{\mathrm{a}}$ & $367^{a}$ \\
\hline Treated & $6.32^{\mathrm{a}}$ & NA & NA & $32.7^{\mathrm{a}}$ & $237^{\mathrm{a}}$ & $875^{\mathrm{cd}}$ & $356^{\mathrm{a}}$ \\
\hline Treated + F & $6.33^{\mathrm{a}}$ & NA & NA & $27.0^{\mathrm{ab}}$ & $263^{a}$ & $980^{\mathrm{b}}$ & $365^{a}$ \\
\hline \multicolumn{8}{|c|}{ Crop Cycle 3} \\
\hline Control & $6.33^{\mathrm{a}}$ & $13.2^{c}$ & $1.5^{\mathrm{c}}$ & $6.48^{\mathrm{e}}$ & $193^{\mathrm{ab}}$ & $816^{b}$ & $226^{\mathrm{d}}$ \\
\hline Control + F & $5.24^{\mathrm{d}}$ & $14.2^{\mathrm{c}}$ & $1.6^{\mathrm{c}}$ & $16.5^{\text {de }}$ & $98.3^{b c}$ & $674^{\mathrm{c}}$ & $151^{\mathrm{e}}$ \\
\hline Untreated & $5.89 \mathrm{bc}$ & $18.5^{\mathrm{b}}$ & $2.1^{b}$ & $24.4^{\mathrm{cd}}$ & $160^{a b c}$ & $916^{a}$ & $361^{b}$ \\
\hline Untreated $+\mathrm{F}$ & $5.79^{c}$ & $26.5^{\mathrm{a}}$ & $2.1^{b}$ & $58.8^{\mathrm{a}}$ & $68.4^{c}$ & $850^{\mathrm{ab}}$ & $272^{c}$ \\
\hline Treated & $5.42^{d}$ & $17.1^{\mathrm{b}}$ & $1.9^{b}$ & $38.1^{b c}$ & $205^{a}$ & $909^{a}$ & $396^{a}$ \\
\hline Treated + F & $6.08^{a}$ & $28.8^{a}$ & $3.2^{\mathrm{a}}$ & $52.4^{\mathrm{a}}$ & $80.3^{c}$ & $911^{\mathrm{a}}$ & $339^{a}$ \\
\hline
\end{tabular}

In the absence of fertilizers, soil nutrient status showed a declining trend with cropping cycle with the exception of $\mathrm{Ca}$, which increased in concentration under both $\mathrm{CC}$ biochar treatments and $\mathrm{P}$ and $\mathrm{Mg}$, which also increased in the third cycle with the treated SS biochar. However, in combination with 
fertilizer, there were some notable differences in biochar type effects on soil nutrient status. While the $\mathrm{CC}$ biochar treatments showed an overall decline in soil nutrient status with the exception of soil $\mathrm{P}$, the SS biochar treatments were more effective at buffering nutrient losses for $\mathrm{K}$ and $\mathrm{Mg}$. Most notable were the increases in soil $\mathrm{P}$ and $\mathrm{Mg}$ content from the SS biochars over three cropping cycles. We also remark that the SS biochars showed lower declines in soil Ca $\left(-77 \mathrm{mg} \cdot \mathrm{kg}^{-1}\right)$ compared with the CC biochars $\left(-253 \mathrm{mg} \cdot \mathrm{kg}^{-1}\right)$. The treated SS biochar was especially effective at maintaining $\mathrm{Ca}$ and $\mathrm{Mg}$ in the soil whereas its untreated counterpart was more effective at enhancing soil P.

Soil C status showed only small changes over the three cropping cycles in the absence of fertilizer with a $0.46 \%$ increase in the untreated CC biochar treatment and a $0.07 \%$ loss in the SS treated biochar treatment. To the contrary, when fertilizer was combined with the SS biochar, soil C increased by almost $1.1 \%$ when the untreated and treated treatments were averaged. The increase in soil $\mathrm{C}$ is likely due to the large enhancement of biomass production, including below-ground biomass, from SS biochars in the third crop.

\subsection{Nutrient Uptake}

In the absence of fertilizer, significant biochar effects on nutrient uptake were limited to the first crop cycle, and were more prevalent in the SS treatments than the CC treatments; the treated CC biochar only improved $\mathrm{N}$ uptake whereas the untreated SS biochar increased all nutrient uptake except $\mathrm{N}$ and $\mathrm{Fe}$ (Table 4). In combination with fertilizer, the SS biochars remained more effective at enhancing nutrient uptake, especially in the third crop cycle. For the CC biochars both the treated and untreated biochars increased P uptake, the treated biochar increased Mg uptake, and the untreated biochar increased $\mathrm{B}$ and $\mathrm{Cu}$ uptake in the first crop. By the third crop, only the untreated CC biochar maintained positive effects on $\mathrm{P}, \mathrm{K}, \mathrm{Mg}, \mathrm{Cu}$ and $\mathrm{Zn}$ uptake. For the SS, both the untreated and treated biochars increased nutrient uptake above the control + fertilizer, except for $\mathrm{N}$ and $\mathrm{Mn}$, which were increased in the untreated SS biochar in the first crop cycle, and $\mathrm{Ca}$, which increased in the treated biochar in the third crop cycle. The magnitude of biochar induced uptake was much higher for the SS in both cropping cycles, but improvements were especially remarkable in the third crop cycle where, for example, we observed a four-fold improvement for $\mathrm{P}$ and a three-fold increase for $\mathrm{Mg}$ above the control + fertilizer treatments. The improved corn nutrient uptake is generally matched by biochars' maintenance or enhancement of the respective nutrients in the soil. This is especially clear for $\mathrm{P}$, where the SS biochars caused substantial increases in available soil P.

Table 4. Corn cob and sewage sludge biochar effects on elemental uptake into corn biomass in the first and third crop cycles. Means followed by same letter are not significantly different $(P<0.05)$ for comparisons made within each crop cycle ( $n=4$ per treatment).

\begin{tabular}{|c|c|c|c|c|c|c|c|c|c|c|}
\hline Treatment & $\mathbf{N}$ & $\mathbf{P}$ & $\mathbf{K}$ & Ca & Mg & B & $\mathrm{Cu}$ & $\mathrm{Fe}$ & Mn & Zn \\
\hline & \multicolumn{5}{|c|}{$\mathrm{mg} \cdot \operatorname{pot}^{-1}$} & \multicolumn{5}{|c|}{$\mathrm{mg} \cdot \operatorname{pot}^{-1}$} \\
\hline \multicolumn{11}{|c|}{ Corn Cob Biochar } \\
\hline \multicolumn{11}{|c|}{ Crop Cycle 1} \\
\hline Control & $23.1^{\mathrm{b}}$ & $1.84^{\mathrm{c}}$ & $82.2^{\mathrm{c}}$ & $10.5^{\mathrm{b}}$ & $5.68^{c}$ & $0.03^{c}$ & $0.02^{\mathrm{c}}$ & $1.10^{\mathrm{ab}}$ & $0.33^{c}$ & $0.08^{\mathrm{cd}}$ \\
\hline Control + F & $228^{a}$ & $14.2^{\mathrm{b}}$ & $493^{b}$ & $47.9^{a}$ & $28.8^{\mathrm{b}}$ & $0.11^{\mathrm{b}}$ & $0.08^{\mathrm{b}}$ & $1.33^{\mathrm{a}}$ & $4.54^{\mathrm{a}}$ & $0.44^{\mathrm{bc}}$ \\
\hline Untreated & $18.6^{\mathrm{b}}$ & $3.92^{\mathrm{c}}$ & $44.9^{c}$ & $4.93^{b}$ & $4.11^{\mathrm{c}}$ & $0.02^{c}$ & $0.005^{c}$ & $1.23^{\mathrm{a}}$ & $0.18^{c}$ & $0.07^{\mathrm{d}}$ \\
\hline Untreated + F & $214^{\mathrm{a}}$ & $27.6^{\mathrm{a}}$ & $852^{\mathrm{a}}$ & $52.4^{\mathrm{a}}$ & $33.5^{\mathrm{ab}}$ & $0.16^{\mathrm{a}}$ & $0.11^{\mathrm{a}}$ & $1.23^{\mathrm{a}}$ & $1.94^{\mathrm{b}}$ & $2.37^{\mathrm{a}}$ \\
\hline Treated & $15.6^{\mathrm{a}}$ & $4.59^{c}$ & $68.9^{c}$ & $4.90^{\mathrm{b}}$ & $4.55^{\mathrm{c}}$ & $0.03^{c}$ & $0.005^{c}$ & $0.05^{b}$ & $0.21^{\mathrm{c}}$ & $0.07^{\mathrm{d}}$ \\
\hline Treated + F & $205^{a}$ & $21.8^{\mathrm{a}}$ & $777^{a}$ & $52.7^{\mathrm{a}}$ & $37.6^{\mathrm{a}}$ & $0.13^{a b}$ & $0.10^{a b}$ & $1.63^{\mathrm{a}}$ & $1.84^{\mathrm{b}}$ & $0.69^{b}$ \\
\hline \multicolumn{11}{|c|}{ Crop Cycle 3} \\
\hline Control & $4.88^{b}$ & $0.79^{c}$ & $36.5^{\mathrm{d}}$ & $4.05^{\mathrm{b}}$ & $2.92^{c}$ & $0.01^{\mathrm{b}}$ & $0.004^{c}$ & $1.31^{\mathrm{ab}}$ & $0.11^{c}$ & $0.02^{b}$ \\
\hline Control + F & $138^{a}$ & $7.38^{b c}$ & $228^{b c}$ & $26.9^{a}$ & $18.3^{\mathrm{b}}$ & $0.09^{\mathrm{a}}$ & $0.042^{b}$ & $3.61^{\mathrm{a}}$ & $8.94^{\mathrm{a}}$ & $0.36^{\mathrm{b}}$ \\
\hline Untreated & $7.41^{\mathrm{b}}$ & $2.93^{c}$ & $68.9^{\mathrm{d}}$ & $6.14^{\mathrm{b}}$ & $5.78^{c}$ & $0.02^{b}$ & $0.005^{c}$ & $0.32^{\mathrm{b}}$ & $0.21^{\mathrm{c}}$ & $0.07^{b}$ \\
\hline Untreated + F & $213^{a}$ & $20.7^{\mathrm{a}}$ & $446^{\mathrm{a}}$ & $34.4^{\mathrm{a}}$ & $29.2^{\mathrm{a}}$ & $0.13^{\mathrm{a}}$ & $0.075^{\mathrm{a}}$ & $1.16^{\mathrm{ab}}$ & $4.58^{b}$ & $2.18^{\mathrm{a}}$ \\
\hline Treated & $13.6^{\mathrm{b}}$ & $3.86^{c}$ & $81.9^{\mathrm{cd}}$ & $6.61^{b}$ & $7.17^{c}$ & $0.03^{b}$ & $0.006^{c}$ & $0.19^{b}$ & $0.24^{c}$ & $0.09^{b}$ \\
\hline Treated + F & $178^{a}$ & $14.3^{\mathrm{ab}}$ & $328^{a b}$ & $24.3^{a}$ & $21.8^{\mathrm{ab}}$ & $0.08^{a}$ & $0.049^{\mathrm{ab}}$ & $0.65^{b}$ & $4.34^{b}$ & $0.42^{b}$ \\
\hline
\end{tabular}


Table 4. Cont.

\begin{tabular}{|c|c|c|c|c|c|c|c|c|c|c|}
\hline Treatment & $\mathbf{N}$ & $\mathbf{P}$ & K & $\mathrm{Ca}$ & $\mathrm{Mg}$ & B & $\mathrm{Cu}$ & $\mathrm{Fe}$ & Mn & $\mathrm{Zn}$ \\
\hline & \multicolumn{5}{|c|}{$\mathrm{mg} \cdot$ pot $^{-1}$} & \multicolumn{5}{|c|}{$\mathrm{mg} \cdot \mathrm{pot}^{-1}$} \\
\hline \multicolumn{11}{|c|}{ Sewage Sludge Biochar } \\
\hline \multicolumn{11}{|c|}{ Crop Cycle 1} \\
\hline Control & $18.3^{d}$ & $1.55^{\mathrm{c}}$ & $57.9^{c}$ & $6.47^{c}$ & $4.09^{c}$ & $0.03^{c}$ & $0.008^{c}$ & $0.16^{\mathrm{b}}$ & $0.18^{\mathrm{d}}$ & $0.36^{\mathrm{d}}$ \\
\hline Control + F & $177^{b c}$ & $10.3^{b c}$ & $284^{b}$ & $20.6^{\mathrm{b}}$ & $14.9^{b c}$ & $0.06^{b c}$ & $0.05^{\mathrm{b}}$ & $1.97^{\mathrm{a}}$ & $1.07^{\mathrm{b}}$ & $0.24^{\mathrm{cd}}$ \\
\hline Untreated & $96.5^{\mathrm{cd}}$ & $17.8^{\mathrm{b}}$ & $299^{b}$ & $19.4^{b c}$ & $20.1^{b}$ & $0.07^{b}$ & $0.04^{b c}$ & $1.33^{\mathrm{ab}}$ & $0.77^{b c}$ & $0.45^{b c}$ \\
\hline Untreated $+\mathrm{F}$ & $381^{\mathrm{a}}$ & $36.9^{\mathrm{a}}$ & $699^{a}$ & $46.3^{\mathrm{a}}$ & $46.8^{\mathrm{a}}$ & $0.16^{\mathrm{a}}$ & $0.11^{\mathrm{a}}$ & $1.39 \mathrm{ab}$ & $3.30^{\mathrm{a}}$ & $1.32^{\mathrm{a}}$ \\
\hline Treated & $59.1^{\mathrm{d}}$ & $15.0^{b c}$ & $178^{\mathrm{bc}}$ & $15.3^{b c}$ & $13.3^{b c}$ & $0.05^{b c}$ & $0.02^{b c}$ & $0.27^{b}$ & $0.34^{\mathrm{cd}}$ & $0.19^{\mathrm{cd}}$ \\
\hline Treated $+\mathrm{F}$ & $251^{\mathrm{b}}$ & $33.2^{\mathrm{a}}$ & $585^{\mathrm{a}}$ & $37.2^{\mathrm{a}}$ & $36.4^{\mathrm{a}}$ & $0.14^{\mathrm{a}}$ & $0.08^{\mathrm{a}}$ & $1.15^{\mathrm{ab}}$ & $0.91 \mathrm{bc}$ & $0.68^{b}$ \\
\hline \multicolumn{11}{|c|}{ Crop Cycle 3} \\
\hline Control & $11.2^{\mathrm{b}}$ & $1.08^{\mathrm{b}}$ & $37.4^{\mathrm{c}}$ & $4.66^{c}$ & $3.08^{b}$ & $0.02^{b}$ & $0.004^{c}$ & $0.15^{b}$ & $0.09^{\mathrm{d}}$ & $0.02^{b}$ \\
\hline Control + F & $139^{a}$ & $8.55^{\mathrm{b}}$ & $202^{b}$ & $28.2^{b}$ & $23.6^{\mathrm{b}}$ & $0.11^{\mathrm{b}}$ & $0.04^{\mathrm{b}}$ & $0.47^{a b}$ & $1.94^{\mathrm{ab}}$ & $0.21^{\mathrm{b}}$ \\
\hline Untreated & $18.7^{\mathrm{b}}$ & $7.36^{\mathrm{b}}$ & $83.2^{c}$ & $7.81^{\mathrm{c}}$ & $10.7^{b}$ & $0.07^{b}$ & $0.006^{c}$ & $0.06^{\mathrm{b}}$ & $0.31^{\mathrm{cd}}$ & $0.09^{b}$ \\
\hline Untreated + F & $207^{\mathrm{a}}$ & $36.5^{\mathrm{a}}$ & $311^{\mathrm{a}}$ & $45.0^{\mathrm{ab}}$ & $74.4^{\mathrm{a}}$ & $0.33^{\mathrm{a}}$ & $0.08^{\mathrm{a}}$ & $0.86^{a b}$ & $2.63^{\mathrm{a}}$ & $0.89^{\mathrm{a}}$ \\
\hline Treated & $20.4^{\mathrm{b}}$ & $8.64^{b}$ & $92.9^{c}$ & $6.86^{c}$ & $9.98^{b}$ & $0.05^{b}$ & $0.007^{c}$ & $0.10^{\mathrm{b}}$ & $0.16^{\mathrm{d}}$ & $0.09^{b}$ \\
\hline Treated + F & $190^{a}$ & $39.2^{\mathrm{a}}$ & $307^{a}$ & $52.2^{a}$ & $79.4^{\mathrm{a}}$ & $0.34^{\mathrm{a}}$ & $0.08^{a}$ & $1.43^{\mathrm{a}}$ & $1.32^{\mathrm{bc}}$ & $0.64^{\mathrm{a}}$ \\
\hline
\end{tabular}

\subsection{Heavy Metal Accumulation}

Concentrations of $\mathrm{As}, \mathrm{Cd}, \mathrm{Cr}$, and $\mathrm{Pb}$ in the above ground tissue of the corn plants were generally below maximum permitted concentrations established by WHO with the following exceptions: As concentration exceeded limits in untreated SS biochar treatment in the first crop and in the control in the third crop; $\mathrm{Cd}$ exceeded the limit in the control in the first crop (Table 5). For As, $\mathrm{Ni}, \mathrm{Pb}$ and Se there were no significant biochar effects on above ground tissue concentrations compared with the control in both the first and third crop cycles. In the first crop, all biochar materials significantly reduced $\mathrm{Cd}$ concentration in the plant tissue whereas in the third crop the SS biochars were more effective in reducing $\mathrm{Cd}$ accumulation. Furthermore, in the third crop, all biochars caused a significant reduction in tissue Co concentration compared with the control. Finally, the treated SS biochar significantly reduced tissue $\mathrm{Cr}$ concentrations compared with the control in the first crop. With the exception of $\mathrm{Cd}$, heavy metal uptake was not affected by biochar treatment (Table 5). The type of biochar affected $\mathrm{Cu}$ and $\mathrm{Zn}$ uptake into the corn biomass. For the $\mathrm{CC}$ biochar, the fertilized untreated material significantly promoted $\mathrm{Cu}$ and $\mathrm{Zn}$ uptake $(\mathrm{P}<0.05)$ compared to the fertilized control in both the first and third crops while the treated CC biochar did not significantly affect uptake (Table 4). For the SS biochars, $\mathrm{Cu}$ and $\mathrm{Zn}$ uptake increased significantly in both the fertilized treated and untreated treatments compared with the control in both crop cycles.

Table 5. Sewage sludge biochar effects on heavy metal accumulation in above-ground corn biomass in fertilized treatments. Means followed by same letter are not significantly different $(\mathrm{P}<0.05)$ for comparisons made within each crop cycle ( $n=4$ per treatment).

\begin{tabular}{|c|c|c|c|c|c|c|c|}
\hline Treatment & As & $\mathrm{Cd}$ & Co & $\mathrm{Cr}$ & $\mathrm{Ni}$ & $\mathrm{Pb}$ & Se \\
\hline \multicolumn{8}{|c|}{ Crop Cycle 1} \\
\hline \multicolumn{8}{|c|}{ Tissue Concentration } \\
\hline & & & & $\mathrm{mg} \cdot \mathrm{kg}^{-1}$ & & & \\
\hline Control & $0.098^{\mathrm{a}}$ & $0.580^{\mathrm{a}}$ & $0.060^{a b}$ & $0.374^{\mathrm{a}}$ & $0.214^{\mathrm{a}}$ & $0.331^{\mathrm{a}}$ & $0.054^{\mathrm{a}}$ \\
\hline CC UT & $0.090^{\mathrm{a}}$ & $0.220^{b}$ & $0.015^{b}$ & $0.239^{a b}$ & $0.191^{\mathrm{a}}$ & $0.183^{a}$ & $0.204^{\mathrm{a}}$ \\
\hline $\mathrm{CC} \mathrm{T}$ & $0.087^{\mathrm{a}}$ & $0.264^{b}$ & $0.019^{a b}$ & $0.278^{a b}$ & $0.129^{a}$ & $0.199^{\mathrm{a}}$ & $0.530^{\mathrm{a}}$ \\
\hline SS UT & $0.116^{\mathrm{a}}$ & $0.140^{b}$ & $0.088^{a}$ & $0.334^{a b}$ & $0.206^{\mathrm{a}}$ & $0.173^{\mathrm{a}}$ & $0.302^{\mathrm{a}}$ \\
\hline SS T & $0.093^{\mathrm{a}}$ & $0.188^{b}$ & $0.044^{\mathrm{ab}}$ & $0.206^{\mathrm{b}}$ & $0.355^{a}$ & $0.132^{\mathrm{a}}$ & $0.370^{\mathrm{a}}$ \\
\hline WHO MPC * & 0.1 & $0.05-0.4$ & $N A$ & 1.0 & $N A$ & $0.05-1.5$ & $N A$ \\
\hline
\end{tabular}


Table 5. Cont.

\begin{tabular}{|c|c|c|c|c|c|c|c|}
\hline Treatment & As & $\mathrm{Cd}$ & Co & $\mathrm{Cr}$ & $\mathbf{N i}$ & $\mathrm{Pb}$ & Se \\
\hline \multicolumn{8}{|c|}{ Crop Cycle 1} \\
\hline \multicolumn{8}{|c|}{ Elemental Uptake } \\
\hline & & & & $\mu \mathrm{g} \cdot \operatorname{pot}^{-1}$ & & & \\
\hline Control & $0.79^{a}$ & $4.66^{\mathrm{a}}$ & $0.49^{\mathrm{a}}$ & $3.02^{\mathrm{a}}$ & $1.72^{\mathrm{a}}$ & $2.65^{\mathrm{a}}$ & $0.44^{\mathrm{a}}$ \\
\hline CC UT & $1.58^{\mathrm{a}}$ & $3.74^{\mathrm{abc}}$ & $0.28^{a}$ & $4.07^{\mathrm{a}}$ & $3.23^{a}$ & $3.13^{\mathrm{a}}$ & $3.33^{a}$ \\
\hline $\mathrm{CC} \mathrm{T}$ & $1.40^{\mathrm{a}}$ & $3.94^{\mathrm{ab}}$ & $0.35^{\mathrm{a}}$ & $4.24^{\mathrm{a}}$ & $2.11^{\mathrm{a}}$ & $3.31^{\mathrm{a}}$ & $8.81^{a}$ \\
\hline SS UT & $1.50^{\mathrm{a}}$ & $1.85^{\mathrm{c}}$ & $1.16^{\mathrm{a}}$ & $4.36^{\mathrm{a}}$ & $2.76^{\mathrm{a}}$ & $2.34^{\mathrm{a}}$ & $3.98^{a}$ \\
\hline SS T & $1.17^{\mathrm{a}}$ & $2.22^{b c}$ & $0.50^{\mathrm{a}}$ & $2.50^{\mathrm{a}}$ & $4.15^{\mathrm{a}}$ & $1.62^{\mathrm{a}}$ & $4.42^{\mathrm{a}}$ \\
\hline \multicolumn{8}{|c|}{ Crop Cycle 3} \\
\hline \multicolumn{8}{|c|}{ Tissue Concentration } \\
\hline & & & & $\mathrm{mg} \cdot \mathrm{kg}^{-1}$ & & & \\
\hline Control & $0.129^{a}$ & $0.363^{a}$ & $0.312^{\mathrm{a}}$ & $0.226^{\mathrm{a}}$ & $0.983^{\mathrm{a}}$ & $0.102^{\mathrm{a}}$ & $0.347^{\mathrm{a}}$ \\
\hline CC UT & $0.089^{a}$ & $0.194^{b c}$ & $0.051^{b}$ & $0.342^{\mathrm{a}}$ & $0.387^{\mathrm{a}}$ & $0.206^{\mathrm{a}}$ & $0.450^{\mathrm{a}}$ \\
\hline $\mathrm{CC} \mathrm{T}$ & $0.084^{\mathrm{a}}$ & $0.279 \mathrm{ab}$ & $0.108^{b}$ & $0.325^{\mathrm{a}}$ & $0.359^{\mathrm{a}}$ & $0.117^{\mathrm{a}}$ & $0.584^{\mathrm{a}}$ \\
\hline SS UT & $0.071^{\mathrm{a}}$ & $0.136^{\mathrm{cd}}$ & $0.037^{b}$ & $0.243^{\mathrm{a}}$ & $0.161^{\mathrm{a}}$ & $0.178^{\mathrm{a}}$ & $0.437^{\mathrm{a}}$ \\
\hline SS T & $0.082^{\mathrm{a}}$ & $0.056^{\mathrm{d}}$ & $0.256^{\mathrm{b}}$ & $0.285^{\mathrm{a}}$ & $0.440^{\mathrm{a}}$ & $0.117^{\mathrm{a}}$ & $0.375^{\mathrm{a}}$ \\
\hline \multicolumn{8}{|c|}{ Elemental Uptake } \\
\hline & & & & $\mu \mathrm{g} \cdot \operatorname{pot}^{-1}$ & & & \\
\hline Control & $0.64^{\mathrm{a}}$ & $1.85^{\mathrm{a}}$ & $1.58^{\mathrm{a}}$ & $1.34^{\mathrm{a}}$ & $4.90^{\mathrm{a}}$ & $0.51^{\mathrm{a}}$ & $1.78^{a}$ \\
\hline CC UT & $0.89^{a}$ & $2.00^{\mathrm{a}}$ & $0.50^{b}$ & $3.62^{\mathrm{a}}$ & $4.12^{\mathrm{a}}$ & $2.04^{\mathrm{a}}$ & $5.11^{\mathrm{a}}$ \\
\hline $\mathrm{CC} \mathrm{T}$ & $0.58^{a}$ & $1.77^{\mathrm{a}}$ & $0.66^{b}$ & $2.05^{\mathrm{a}}$ & $2.16^{\mathrm{a}}$ & $0.82^{\mathrm{a}}$ & $4.38^{a}$ \\
\hline SS UT & $0.93^{\mathrm{a}}$ & $1.80^{\mathrm{a}}$ & $0.49^{b}$ & $3.25^{\mathrm{a}}$ & $2.13^{\mathrm{a}}$ & $2.45^{\mathrm{a}}$ & $5.70^{a}$ \\
\hline SS T & $1.55^{\mathrm{a}}$ & $1.00^{\mathrm{a}}$ & $0.53^{b}$ & $5.40^{\mathrm{a}}$ & $7.50^{\mathrm{a}}$ & $2.35^{\mathrm{a}}$ & $5.82^{a}$ \\
\hline
\end{tabular}

* Maximum permitted concentration [56].

\section{Discussion}

\subsection{Plant Growth}

Overall, results from the greenhouse experiments demonstrated significant biochar benefits to plant growth. The benefits were mostly observed when biochar materials were combined with fertilizer, except in the case of the untreated SS biochar, which produced plant growth comparable to the fertilized control in the first crop cycle only. For the sewage sludge biochars, increases of dry matter biomass relative to the control were higher than reported sewage sludge biochar effects on tomato $[20,22]$ and similar to results reported for rice shoot weight [21]. By the third crop cycle, however, benefits from SS biochars were in excess of $250 \%$ compared with the chemical control, which is at the high end of reported growth responses to biochar [23].

Although biochar showed promise as a biofilm support increasing microbial activity in an anaerobic digestion system [41] and the anaerobically treated SS biochar showed a higher concentration of bioavailable macronutrients compared to its untreated counterpart, the nutrient enriched biochar produced no significant added benefit to plant growth in any of the greenhouse experiments. These results are in contrast to recent work showing that P-enriched biochar used in an anaerobic digestion system significantly improved early seedling germination and shoot growth [45].

Plant growth response to biochar application was related to improvements in soil nutrient status in the first crop cycle, and evidence for apparent alleviation of Mn toxicity, especially in the SS biochar treated soils in the third crop cycle. In the first crop cycle, results from regression analysis demonstrated that plant growth response to CC biochar treatments were significantly correlated to improvements in soil $\mathrm{pH}$ and extractable macronutrients (Figure 2). The CC biochar materials were effective at raising soil $\mathrm{pH}$ from near 6 to above 7 with a significant linear growth response up to about $\mathrm{pH} 6.5$ (Figure 2a). 
Corn growth showed a strong response to increasing $\mathrm{P}$ availability from biochar application, but the highest soil $\mathrm{P}$ concentrations achieved with the treated CC biochar application did not contribute to added plant growth (Figure $2 \mathrm{~b}$ ). Both the treated and untreated CC biochars more than doubled extractable $\mathrm{K}$ in the soils and contributed significantly to plant growth response (Figure 2c) with biochar derived $\mathrm{Ca}$ also contributing significantly to plant growth (Figure 2d). In addition to responses to changes in soil $\mathrm{pH}$ and extractable nutrients, plant growth response was also significantly related to decreases in tissue Mn concentration (Figure 3). For the SS biochar treatments in the first crop, plant growth responses were primarily explained by biochar derived increases in extractable base cation concentrations in the soil. The results for both biochar materials in our study agree with previous research demonstrating that direct contributions of mineral nutrients in the biochar ash component play an important role in remediating acidic soils and promoting plant growth $[13,27,28,57-59]$.
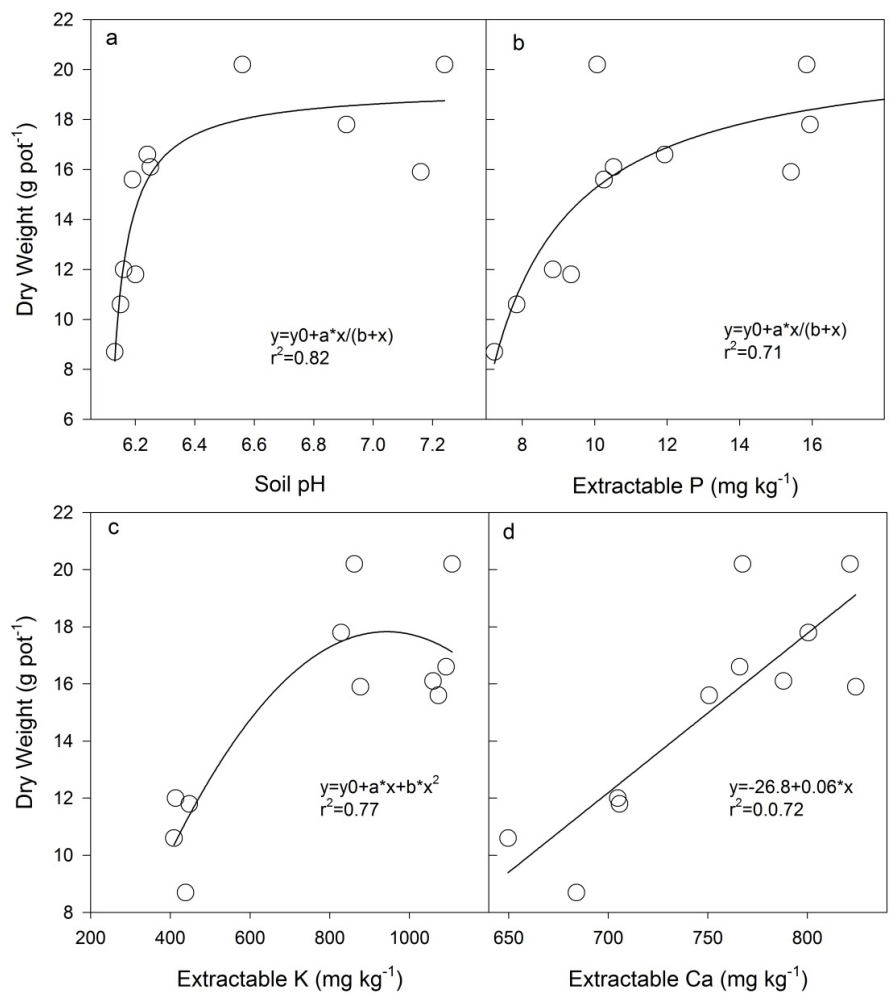

Figure 2. Corn above-ground dry weight biomass response to increasing soil $\mathrm{pH}$ (a); extractable $\mathrm{P}$ (b); $\mathrm{K}(\mathbf{c})$; and $\mathrm{Ca}(\mathbf{d})$ in control and biochar amended soils with fertilizer.

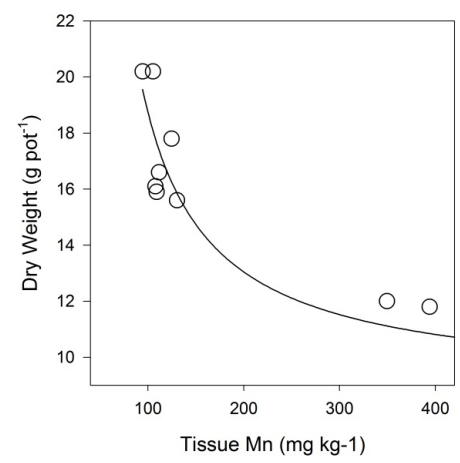

Figure 3. Above-ground corn dry weight biomass response to $\mathrm{CC}$ biochar treatments in the first crop cycle. 
By the third crop cycle, we observed distinct differences in the effects of the two biochar materials. First, benefits to plant growth by the CC biochars were much reduced in the third crop with significant effects on growth limited to the untreated biochar. On the other hand, the SS biochars showed increasing benefits to plant growth over time and no differences between the treated or untreated biochars. Previous research has reported varying effects of time on biochar performance. In a greenhouse experiment evaluating the use of Flash Carbonized corn cob biochar applied to an acid Ultisol the benefits were short-lived and did not persist beyond the first crop cycle [27]. In contrast, a Flash Carbonized eucalyptus biochar showed no effect on plant growth in the first crop, but produced significant benefits to plant growth in the second crop [13]. At the field scale, there is some evidence that biochar benefits to crop growth are not realized in the first crop cycle, but take time to manifest themselves [60-62].

The persistence of a biochar liming effect controlling soil Mn bioavailability accompanied by improved nutrient availability were the primary drivers responsible for a positive plant growth response in the third crop; the effects were particularly notable in the SS biochar treated soils.

The SS biochar amended soils maintained a higher $\mathrm{pH}$, which significantly reduced $\mathrm{Mn}$ bioavailability; plants in the unamended control exhibited toxic levels of $\mathrm{Mn}$ in the above-ground biomass (Figure 4a), which significantly inhibited plant growth compared with plants in the biochar treatments (Figure 4b). Both the treated and untreated biochars continued to provide a liming benefit with the treated biochar delivering significantly better liming power than its untreated counterpart. The liming value of sewage sludge biochars has been reported in previous research $[21,22]$. The biochar's liming potential significantly reduced Mn bioavailability lowering tissue Mn concentration more than fourfold compared with the control, and below the limit of $200 \mathrm{mg} \cdot \mathrm{kg}^{-1}$ set for phytotoxicity in corn [53] (Figure 5a). Lower Mn in the aboveground tissue was the primary reason for higher yields in the biochar amended plots. Biochar-mediated liming reduced soil Mn solubility 5 -fold in the untreated SS biochar and by more than 30-fold in its treated counterpart (Figure 5a). Low Mn concentrations in the saturated paste extract corresponded to low tissue Mn (Figure $6 b$ ) and much higher corn growth (Figure 5c). Recent greenhouse work reported that biochar alleviated Mn toxicity and improved corn growth in an Mn-rich Oxisol [13]. They attributed the remediation effect to improved $\mathrm{Ca}$ uptake with a reduction in $\mathrm{Mn}: \mathrm{Ca}$ ratio in the plant tissue and organo-Mn complexation reactions inhibiting plant Mn uptake. Our results indicated that the high ash biochar directly detoxified Mn by reducing Mn solubility, but given the complexity of Mn reactions in soil, biochar mediated Mn detoxification merits further study.
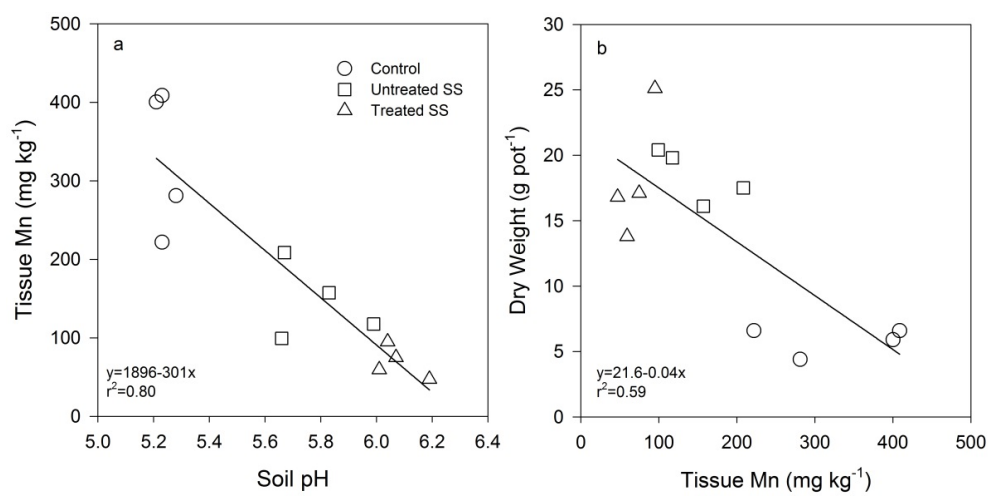

Figure 4. Sewage sludge biochar effects on soil $\mathrm{pH}$ and tissue Mn concentrations (a), and above-ground corn biomass (b), in relation to an unamended control (all treatments supplemented with fertilizer) in the third crop cycle. 

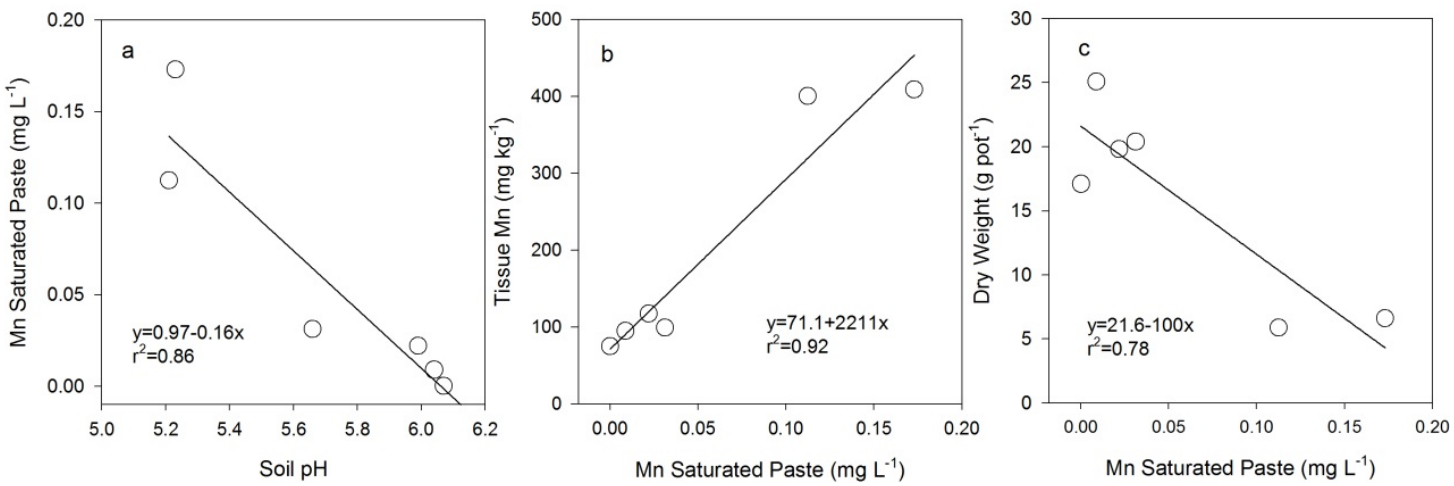

Figure 5. Sewage sludge biochar effects on soil $\mathrm{pH}$ and soil Mn concentrations (a); tissue Mn concentrations (b); and above-ground corn biomass (c) in relation to an unamended control (all treatments supplemented with fertilizer) in the third crop cycle.
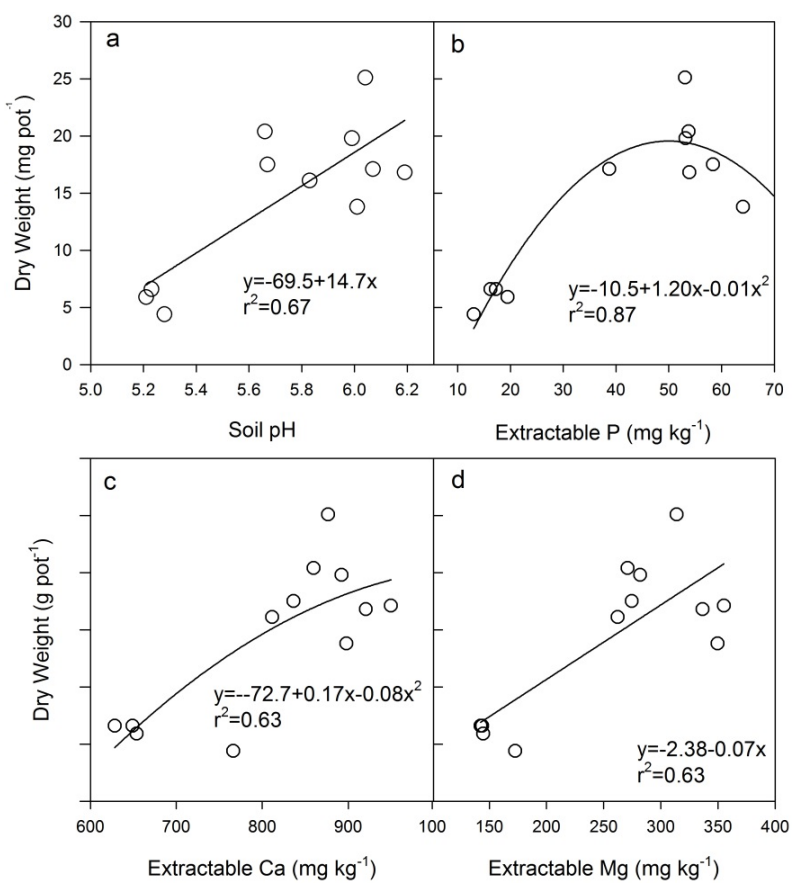

Figure 6. Sewage sludge biochar effects on soil $\mathrm{pH}(\mathbf{a})$; extractable $\mathrm{P}(\mathbf{b})$; $\mathrm{Ca}(\mathbf{c})$; and $\mathrm{Mg}(\mathbf{d})$ in relation to above-ground biomass in the third crop cycle.

In addition to its liming effect and associated detoxification of $\mathrm{Mn}$, the SS biochars continued to supply essential nutrients through the third crop cycle contributing to improved plant growth. The maintenance of elevated soil $\mathrm{pH}$, extractable $\mathrm{P}, \mathrm{Ca}$, and $\mathrm{Mg}$ corresponded to higher corn growth (Figure 6). We associate the persistence of a beneficial liming effect and elemental nutrient contribution promoting plant growth to the high ash content of the SS biochars in comparison to the lower ash CC biochars. The high P content of the SS biochars appeared to play an important role in promoting plant growth. The SS biochar amended soils showed a 4 to 6-fold increases in extractable soil P compared with the control soils, which corresponded to as much as a 4-fold increase in plant growth. These results agree with previous research demonstrating that biochars made from various feedstocks increase $P$ solubility in soils [63] and serve as a slow-release form of $\mathrm{P}$ fertilizer [44,45,64]. A recent study utilizing a range of biochar materials showed that plant growth was highly correlated with $\mathrm{P}$ content of the biochar material with the high P sewage sludge biochar yielding the best plant growth response [19]. 
Overall, these results provide further evidence in support of the contention that agronomic benefits of biochar addition to soils are primarily associated with the ash component [23].

\subsection{Heavy Metal Accumulation}

Raw sewage sludge materials are typically high in pathogens and heavy metal concentrations making their application to land a potential source of contamination and hazardous to human health. Although carbonization of the raw feedstock tended to concentrate heavy metals in the biochar product, metal concentrations in the biochars did not exceed the ceiling concentration defined by the U.S. EPA [54] and the European Union (EU) [65]. However, when we consider the biochar loading rate in this series of experiments, levels of $\mathrm{Cd}, \mathrm{Cu}$, and $\mathrm{Zn}$ delivered by the $\mathrm{SS}$ biochars exceed the loading rates permitted by the EU. Therefore, in order to meet land application regulations, the SS biochar loading rates would need to be decreased by as much as 4 -fold. According to regulations set by the State of Hawaii, the untreated CC and treated SS biochars exceeded the maximum allowable concentration for Mo, and both SS biochars exceeded the limits for Zn [55]. Thus, according to current regulations in the State of Hawaii, none of these biochars are permitted for land application. Similarly high $\mathrm{Zn}$ concentrations were measured in a number of sewage sludge biochars from various waste water treatment facilities $[12,15,19,66,67]$.

There is a growing body of evidence demonstrating that sewage sludge biochars reduce heavy metal bioavailability in the soil and their accumulation in plants $[14,20,21,68,69]$. With the exception of $\mathrm{Cd}$ where the SS biochars significantly reduced plant uptake in the first crop cycle, our results showed no significant effect of biochars on heavy metal accumulation. Overall, metal concentrations in the corn tissue were below the WHO maximum permitted concentrations in the biochar amended soils. While these results do not support the general trend that biochar reduces metal availability, the lack of a significant effect compared to the control soils, from an agronomic perspective is important because it suggests that the sludge biochar is not a source of metal contamination for food crops allaying potential concerns from a food safety perspective.

\section{Conclusions}

Both the CC and SS biochars showed significant improvements to corn growth in combination with fertilizer in short term pot experiments. With fertilizer supplements, benefits to plant growth persisted and increased over the three cropping cycles in the SS biochar treated soils whereas benefits from the corn cob biochar were more short-term. Anaerobically treated biochars, enriched in essential plant nutrients, did not improve plant growth in comparison to their untreated counterparts except for the treated SS biochar, but its benefit did not persist beyond the first crop cycle. In addition to direct contributions of essential nutrients $(\mathrm{P}, \mathrm{Ca}, \mathrm{Mg}, \mathrm{K})$ from the ash-rich SS biochars, a persistent liming effect effectively countered the negative impacts of Mn toxicity brought about by the acidification of the soil from nitrogen fertilization.

Although the dramatic increases in plant growth with SS biochar amendments, coupled with no increase in heavy metal accumulation in crop biomass in the greenhouse bioassays, suggests that the pyrolytic conversion of sewage sludge into beneficial biochar is a potential alternative to the current practice of disposal in dwindling landfill space, the heavy metal concentration of the SS biochar remains problematic for land application. In addition, loading rates utilized in this experiment deliver excess $\mathrm{Cd}, \mathrm{Cu}$ and $\mathrm{Zn}$ to the soil beyond some of the established regulatory limits. Despite these drawbacks, the evidence showing that thermal treatment of the sludge reduces heavy metal bioavailability is reason enough to continue exploring its use as a potentially beneficial soil amendment with a focus on application rates and metal bioavailability at the field scale. Of particular importance is the need to validate the persistence of biochar derived benefits over multiple crop cycles with just one application of the biochar material.

Supplementary Materials: The following are available online at http://www.mdpi.com/2071-1050/8/2/131/s1: Table S1: Deenik Supplemental Data. 
Acknowledgments: The research was supported by a University of Hawaii at Manoa Sustainability Grant. The authors thank Michael Jerry Antal, Jr. for providing the biochar materials, Joshua Niepp and Elyssa Ermatinger for assisting in the implementation, maintenance, and data collection from the greenhouse experiments, and their work in laboratory.

Author Contributions: Jonathan L. Deenik conceived and designed the experiments, performed data analysis, and drafted the manuscript. Michael J. Cooney conceived and designed experiments and edited the manuscript.

Conflicts of Interest: The authors declare no conflict of interest.

\section{Abbreviations}

The following abbreviations are used in this manuscript:

MDPI: Multidisciplinary Digital Publishing Institute

DOAJ: Directory of open access journals

TLA: Three letter acronym

LD: linear dichroism

\section{References}

1. Fytili, D.; Zabaniotou, A. Utilization of sewage sludge in eu application of old and new methods-A review. Renew. Sustain. Energy Rev. 2008, 12, 116-140. [CrossRef]

2. Chen, H. Utilization of urban sewage sludge: Chinese perspectives. Environ. Sci. Pollut. Res. Int. 2012, 19, 1454-1463. [CrossRef] [PubMed]

3. Fonts, I.; Gea, G.; Azuara, M.; Ábrego, J.; Arauzo, J. Sewage sludge pyrolysis for liquid production: A review. Renew. Sustain. Energy Rev. 2012, 16, 2781-2805. [CrossRef]

4. Lu, Q.; He, Z.L.; Stoffella, P.J. Land application of biosolids in the USA: A review. Appl. Environ. Soil Sci. 2012, 2012, 11. [CrossRef]

5. Services, D.O.E. 2013 Interim Status Report on the Integrated Solid Waste Management Plan (2008); Services, D.O.E., Ed.; Department of Environmental Services City and County of Honolulu: Honolulu, HI, USA, 2013.

6. Laird, D.A. The charcoal vision: A win win win scenario for simultaneously producing bioenergy, permanently sequestering carbon, while improving soil and water quality. Agron. J. 2008, 100, 178-181. [CrossRef]

7. Jeffery, S.; Verheijen, F.G.A.; van der Velde, M.; Bastos, A.C. A quantitative review of the effects of biochar application to soils on crop productivity using meta-analysis. Agric. Ecosyst. Environ. 2011, 144, 175-187. [CrossRef]

8. Manyà, J.J. Pyrolysis for biochar purposes: A review to establish current knowledge gaps and research needs. Environ. Sci. Technol. 2012, 46, 7939-7954. [CrossRef] [PubMed]

9. Verheijen, F.G.A.; Graber, E.R.; Ameloot, N.; Bastos, A.C.; Sohi, S.; Knicker, H. Biochars in soils: New insights and emerging research needs. Eur. J. Soil Sci. 2014, 65, 22-27. [CrossRef]

10. Gascó, G.; Paz-Ferreiro, J.; Méndez, A. Thermal analysis of soil amended with sewage sludge and biochar from sewage sludge pyrolysis. J. Therm. Anal. Calorim. 2012, 108, 769-775. [CrossRef]

11. Agrafioti, E.; Bouras, G.; Kalderis, D.; Diamadopoulos, E. Biochar production by sewage sludge pyrolysis. J. Anal. Appl. Pyrolysis 2013, 101, 72-78. [CrossRef]

12. Méndez, A.; Terradillos, M.; Gascó, G. Physicochemical and agronomic properties of biochar from sewage sludge pyrolysed at different temperatures. J. Anal. Appl. Pyrolysis 2013, 102, 124-130. [CrossRef]

13. Butnan, S.; Deenik, J.L.; Toomsan, B.; Antal, M.J.; Vityakon, P. Biochar characteristics and application rates affecting corn growth and properties of soils contrasting in texture and mineralogy. Geoderma 2015, 237, 105-116. [CrossRef]

14. Liu, T.; Liu, B.; Zhang, W. Nutrients and heavy metals in biochar produced by sewage sludge pyrolysis: Its application in soil amendment. Pol. J. Environ. Stud. 2014, 23, 271-275.

15. Lu, H.; Zhang, W.; Wang, S.; Zhuang, L.; Yang, Y.; Qiu, R. Characterization of sewage sludge-derived biochars from different feedstocks and pyrolysis temperatures. J. Anal. Appl. Pyrolysis 2013, 102, 137-143. [CrossRef]

16. Hossain, M.K.; Strezov, V.; Chan, K.Y.; Ziolkowski, A.; Nelson, P.F. Influence of pyrolysis temperature on production and nutrient properties of wastewater sludge biochar. J. Environ. Manag. 2011, 92, 223-228. [CrossRef] [PubMed] 
17. Srinivasan, P.; Sarmah, A.K.; Smernik, R.; Das, O.; Farid, M.; Gao, W. A feasibility study of agricultural and sewage biomass as biochar, bioenergy and biocomposite feedstock: Production, characterization and potential applications. Sci. Total Environ. 2015, 512, 495-505. [CrossRef] [PubMed]

18. Zhang, J.; Lü, F.; Zhang, H.; Shao, L.; Chen, D.; He, P. Multiscale visualization of the structural and characteristic changes of sewage sludge biochar oriented towards potential agronomic and environmental implication. Sci. Rep. 2015, 5. [CrossRef] [PubMed]

19. Marks, E.A.N.; Alcaniz, J.M.; Domene, X. Unintended effects of biochars on short-term plant growth in a calcareous soil. Plant Soil 2014, 385, 87-105. [CrossRef]

20. Hossain, M.K.; Strezov, V.; Nelson, P.F. Comparative assessment of the effect of wastewater sludge biochar on growth, yield and metal bioaccumulation of cherry tomato. Pedosphere 2015, 25, 680-685. [CrossRef]

21. Khan, S.; Chao, C.; Waqas, M.; Arp, H.P.H.; Zhu, Y.G. Sewage sludge biochar influence upon rice (oryza sativa 1) yield, metal bioaccumulation and greenhouse gas emissions from acidic paddy soil. Environ. Sci. Technol. 2013, 47, 8624-8632. [PubMed]

22. Hossain, M.K.; Strezov, V.; Yin Chan, K.; Nelson, P.F. Agronomic properties of wastewater sludge biochar and bioavailability of metals in production of cherry tomato (lycopersicon esculentum). Chemosphere 2010, 78, 1167-1171. [CrossRef] [PubMed]

23. Biederman, L.A.; Harpole, W.S. Biochar and its effects on plant productivity and nutrient cycling: A meta-analysis. GCB Bioenergy 2013, 5, 202-214. [CrossRef]

24. Glaser, B.; Lehmann, J.; Zech, W. Ameliorating physical and chemical properties of highly weathered soils in the tropics with charcoal-A review. Biol. Fertil. Soils 2002, 35, 219-230. [CrossRef]

25. Liang, B.; Lehmann, J.; Solomon, D.; Kinyangi, J.; Grossman, J.; O’Neill, B.; Skjemstad, J.O.; Thies, J.; Luizao, F.J.; Petersen, J.; et al. Black carbon increases cation exchange capacity in soils. Soil Sci. Soc. Am. J. 2006, 70, 1719-1730. [CrossRef]

26. Chan, K.Y.; Van Zwieten, L.; Meszaros, I.; Downie, A.; Joseph, S. Agronomic values of greenwaste biochar as a soil amendment. Aust. J. Soil Res. 2007, 45, 629-634. [CrossRef]

27. Deenik, J.L.; Diarra, A.; Uehara, G.; Campbell, S.; Sumiyoshi, Y.; Antal, M.J. Charcoal ash and volatile matter effects on soil properties and plant growth in an acid ultisol. Soil Sci. 2011, 176, 336-345. [CrossRef]

28. Deenik, J.L.; McClellan, T.; Uehara, G.; Antal, M.J.; Campbell, S. Charcoal volatile matter content influences plant growth and soil nitrogen transformations. Soil Sci. Soc. Am. J. 2010, 74, 1259-1270. [CrossRef]

29. Lehmann, J.; Rillig, M.C.; Thies, J.; Masiello, C.A.; Hockaday, W.C.; Crowley, D. Biochar effects on soil biota-A review. Soil Biol. Biochem. 2011, 43, 1812-1836. [CrossRef]

30. Viger, M.; Hancock, R.D.; Miglietta, F.; Taylor, G. More plant growth but less plant defence? First global gene expression data for plants grown in soil amended with biochar. Glob. Chang. Biol. Bioenergy 2015, 7, 658-672. [CrossRef]

31. Gundale, M.J.; DeLuca, T.H. Charcoal effects on soil solution chemistry and growth of koeleria macrantha in the ponderosa pine/douglas-fir ecosystem. Biol. Fertil. Soils 2007, 43, 303-311. [CrossRef]

32. Buss, W.; Masek, O. Mobile organic compounds in biochar-A potential source of contamination-Phytotoxic effects on cress seed (lepidium sativum) germination. J. Environ. Manag. 2014, 137, 111-119. [CrossRef] [PubMed]

33. Buss, W.; Mašek, O.; Graham, M.; Wüst, D. Inherent organic compounds in biochar-their content, composition and potential toxic effects. J. Environ. Manag. 2015, 156, 150-157. [CrossRef] [PubMed]

34. Zheng, R.L.; Cai, C.; Liang, J.H.; Huang, Q.; Chen, Z.; Huang, Y.Z.; Arp, H.P.H.; Sun, G.X. The effects of biochars from rice residue on the formation of iron plaque and the accumulation of $\mathrm{cd}, \mathrm{zn}, \mathrm{pb}$, as in rice (oryza sativa 1.) seedlings. Chemosphere 2012, 89, 856-862. [CrossRef] [PubMed]

35. Ahmad, M.; Rajapaksha, A.U.; Lim, J.E.; Zhang, M.; Bolan, N.; Mohan, D.; Vithanage, M.; Lee, S.S.; Ok, Y.S. Biochar as a sorbent for contaminant management in soil and water: A review. Chemosphere 2014, 99, 19-33. [CrossRef] [PubMed]

36. Anawar, H.M.; Akter, F.; Solaiman, Z.M.; Strezov, V. Biochar: An emerging panacea for remediation of soil contaminants from mining, industry and sewage wastes. Pedosphere 2015, 25, 654-665. [CrossRef]

37. Beesley, L.; Moreno-Jiménez, E.; Gomez-Eyles, J.L.; Harris, E.; Robinson, B.; Sizmur, T. A review of biochars' potential role in the remediation, revegetation and restoration of contaminated soils. Environ. Pollut. 2011, 159, 3269-3282. [CrossRef] [PubMed] 
38. Park, J.H. Biochar reduces the bioavailability and phytotoxicity of heavy metals. Plant Soil 2011, 348, $439-451$. [CrossRef]

39. Inyang, M.; Gao, B.; Yao, Y.; Xue, Y.; Zimmerman, A.R.; Pullammanappallil, P.; Cao, X. Removal of heavy metals from aqueous solution by biochars derived from anaerobically digested biomass. Bioresour. Technol. 2012, 110, 50-56. [CrossRef] [PubMed]

40. Liu, Z.; Zhang, F.-S. Removal of lead from water using biochars prepared from hydrothermal liquefaction of biomass. J. Hazard. Mater. 2009, 167, 933-939. [CrossRef] [PubMed]

41. Lopez, R.J.; Higgins, S.R.; Pagaling, E.; Yan, T.; Cooney, M.J. High rate anaerobic digestion of wastewater separated from grease trap waste. Renew. Energy 2014, 62, 234-242. [CrossRef]

42. Mohan, D.; Sarswat, A.; Ok, Y.S.; Pittman, C.U., Jr. Organic and inorganic contaminants removal from water with biochar, a renewable, low cost and sustainable adsorbent-A critical review. Bioresour. Technol. 2014, 160, 191-202. [CrossRef] [PubMed]

43. Yao, Y.; Gao, B.; Inyang, M.; Zimmerman, A.R.; Cao, X.; Pullammanappallil, P.; Yang, L. Biochar derived from anaerobically digested sugar beet tailings: Characterization and phosphate removal potential. Bioresour. Technol. 2011, 102, 6273-6278. [CrossRef] [PubMed]

44. Angst, T.E.; Sohi, S.P. Establishing release dynamics for plant nutrients from biochar. GCB Bioenergy 2013, 5, 221-226. [CrossRef]

45. Yao, Y.; Gao, B.; Chen, J.; Yang, L. Engineered biochar reclaiming phosphate from aqueous solutions: Mechanisms and potential application as a slow-release fertilizer. Environ. Sci. Technol. 2013, 47, 8700-8708. [CrossRef] [PubMed]

46. Antal, M.J.; Mochidzuki, K.; Paredes, L.S. Flash carbonization of biomass. Ind. Eng. Chem. Res. 2003, 42, 3690-3699. [CrossRef]

47. Armas, C.M.; Santana, B.; Mora, J.L.; Notario, J.S.; Arbelo, C.D.; Rodríguez-Rodríguez, A. A biological quality index for volcanic andisols and aridisols (canary islands, spain): Variations related to the ecosystem degradation. Sci. Total Environ. 2007, 378, 238-244. [CrossRef] [PubMed]

48. Ayers, A.S.; Hagihara, H.H. Available phosphorus in hawaiian soil profiles. Hawaii. Plant. Rec. 1952, 54, 81-99.

49. Gentry, C.E.; Willis, R.B. Improved method for automated-determination of ammonium in soil extracts. Commun. Soil Sci. Plant Anal. 1988, 19, 721-737. [CrossRef]

50. Mulvaney, R.L. Nitrogen-Inorganic Forms; Soil Science Society of America and American Society of Agronomy: Madison, WI, USA, 1996; pp. 1123-1184.

51. Soil Conservation Service. Soil Survey Laboratory Data and Descriptions for Some Soils of Hawaii; Soil Conservation Service, U.S. Department of Agriculture: Washington, DC, USA, 1976.

52. Hue, N.V.; Uchida, R.; Ho, M.C. Sampling and analysis of soils and plant tissues. In Plant Nutrient Management in Hawaii Soils; Silva, J.A., Uchida, R.S., Eds.; College of Tropical Agriculture and Human Resources, University of Hawaii: Honolulu, HI, USA, 2000; pp. 23-30.

53. Porter, G.S.; Bajita-Locke, J.B.; Hue, N.V.; Strand, D. Manganese solubility and phytotoxicity affected by soil moisture, oxygen levels, and green manure additions. Commun. Soil Sci. Plant Anal. 2004, 35, 99-116. [CrossRef]

54. Environmental Protection Agency. Part 503-Standards for the Use or Disposal of Sewage Sludge; Agency, E.P., Ed.; EPA: Washington, DC, USA, 2013.

55. Hawaii Department of Health. Hawaii Administrative Rules Title 11 Wastewater Systems; Hawaii Department of Health: Honolulu, HI, USA, 2004.

56. World Health Organization. Codex Alimentarius Commission; CF/5 INF/1; World Health Organization: Geneva, Switzerland, 2011.

57. Smider, B.; Singh, B. Agronomic performance of a high ash biochar in two contrasting soils. Agric. Ecosyst. Environ. 2014, 191, 99-107. [CrossRef]

58. Xu, G.; Wei, L.L.; Sun, J.N.; Shao, H.B.; Chang, S.X. What is more important for enhancing nutrient bioavailability with biochar application into a sandy soil: Direct or indirect mechanism? Ecol. Eng. 2013, 52, 119-124. [CrossRef]

59. Chan, K.Y.; Van Zwieten, L.; Meszaros, I.; Downie, A.; Joseph, S. Using poultry litter biochars as soil amendments. Aust. J. Soil Res. 2008, 46, 437-444. [CrossRef] 
60. Major, J.; Rondon, M.; Molina, D.; Riha, S.; Lehmann, J. Maize yield and nutrition during 4 years after biochar application to a colombian savanna oxisol. Plant Soil 2010, 333, 117-128. [CrossRef]

61. Quilliam, R.S.; Glanville, H.C.; Wade, S.C.; Jones, D.L. Life in the "charosphere"-Does biochar in agricultural soil provide a significant habitat for microorganisms? Soil Biol. Biochem. 2013, 65, 287-293. [CrossRef]

62. Quilliam, R.S.; Marsden, K.A.; Gertler, C.; Rousk, J.; DeLuca, T.H.; Jones, D.L. Nutrient dynamics, microbial growth and weed emergence in biochar amended soil are influenced by time since application and reapplication rate. Agric. Ecosyst. Environ. 2012, 158, 192-199. [CrossRef]

63. Wang, T.; Camps-Arbestain, M.; Hedley, M.; Bishop, P. Predicting phosphorus bioavailability from high-ash biochars. Plant Soil 2012, 357, 173-187. [CrossRef]

64. Wang, Y.; Lin, Y.X.; Chiu, P.C.; Imhoff, P.T.; Guo, M.X. Phosphorus release behaviors of poultry litter biochar as a soil amendment. Sci. Total Environ. 2015, 512, 454-463. [CrossRef] [PubMed]

65. European Union. Council Directive 86/278/eec of 12 June 1986 on the Protection of the Environment, and in Particular of the Soil, When Sewage Sludge is Used in Agriculture; European Union: Brussels, Belgium, 2009.

66. Paz-Ferreiro, J.; Fu, S.L.; Mendez, A.; Gasco, G. Interactive effects of biochar and the earthworm pontoscolex corethrurus on plant productivity and soil enzyme activities. J. Soils Sediments 2014, 14, 483-494. [CrossRef]

67. Zielinska, A.; Oleszczuk, P. The conversion of sewage sludge into biochar reduces polycyclic aromatic hydrocarbon content and ecotoxicity but increases trace metal content. Biomass Bioenergy 2015, 75, 235-244. [CrossRef]

68. Fellet, G.; Marmiroli, M.; Marchiol, L. Elements uptake by metal accumulator species grown on mine tailings amended with three types of biochar. Sci. Total Environ. 2014, 468, 598-608. [CrossRef] [PubMed]

69. Méndez, A.; Gómez, A.; Paz-Ferreiro, J.; Gascó, G. Effects of sewage sludge biochar on plant metal availability after application to a mediterranean soil. Chemosphere 2012, 89, 1354-1359. [CrossRef] [PubMed]

(C) 2016 by the authors; licensee MDPI, Basel, Switzerland. This article is an open access article distributed under the terms and conditions of the Creative Commons by Attribution (CC-BY) license (http:/ / creativecommons.org/licenses/by/4.0/). 